\title{
Evaluation of Investment Attractiveness of Russian Airports Based on Factors of Regional Socioeconomic Development
}

\author{
Alexandr Victorovich Gubenko ${ }^{1}$ \\ Svetlana Anatolyevna Borodulina2 \\ Elena Victorovna Budrina ${ }^{3}$ \\ Elena Olegovna Chebakova ${ }^{4}$ \\ ${ }^{1}$ Saint Petersburg State University of Civil Aviation, Vice Chancellor on Research and Economics \\ Saint Petersburg, Russian Federation \\ 2ITMO University, Department of Transportation Systems Management, \\ Saint Petersburg, Russian Federation \\ 3ITMO University, Head of Department of Transportation Systems Management \\ Saint Petersburg, Russian Federation \\ ${ }^{4}$ Siberian State Automobile and Highway Academy, Vice Chancellor for Academic Affairs, Omsk, Russian Federation \\ Correspondence: Svetlana Anatolyevna Borodulina, 197227, Baikonurskaya st., 7-1-486, Saint Petersburg \\ Russian Federation; E-mail: piter00000@mail.ru
}

Doi:10.5901/mjss.2015.v6n5s4p309

\section{Abstract}

The article describes methods for evaluating investment attractiveness of Russian airports. It demonstrates results of studying regional economy development factors, such as business scales, degree of innovations in regions, demographic and other factors that significantly influence on the parameters of the demand for air services, potential incomes, and passenger traffic of airports. Interdependence between the passenger traffic of airports, the factors of commercial activity, and the regional business scales was revealed through the implementation of economical and mathematical methods. This dependence allows for assessment of further investment benefits. A model for evaluating the investment rating of airport enterprises was proposed. This model enables potential investors to have a true and fair idea of future investment effectiveness at the stage of airport engineering and at the stage of current operation of existing evolutive airport enterprises. Scoring technique for evaluating airport investment attractiveness was developed. The results of investment rating calculations for a group of airports in the Far East were presented.

Keywords: air transport, investments in airports, regional factors, scale of business economics, commercial activity of regions, demographic factors of Russian regions development, airport investment rating, investment attractiveness scoring for airport enterprises

\section{Introduction}

Since the time of consolidated aviation enterprises division into private airlines and airport enterprises (AE), the market environment has set new challenges in front of their leaders, in particular, the challenges of airport infrastructure renovation. Airport industry in Russia is characterized by the high degree of development unevenness. Essentially large share of all air transportations is concentrated in the Moscow Air Hub (MAH) comprising 4 airports, wherein each airport features an autonomous system of planning and development.

It should be noted that the state of Russian airfield control network requires annual funding for development amounting to over 65 billion rubles. For reconstruction of the airports selected and maintenance of their operational status, the regionally divided Federal Target Programs (FTPs) were adopted. Currently, only 63\% of airfields out of 304 airports in Russia are complete with paved runways (PRW); while other airfields have unpaved runways (URW). $70 \%$ of airfields are equipped with the system of runway lighting. Over the past 11 years, only $25 \%$ of PRW were subject to reconstruction. Now, $12 \%$ of paved runways require urgent reconstruction, and $18 \%$ of unpaved runways need major overhaul. One of the main reasons for the situation existing in the land base is an insufficient volume of investments intended for maintenance and development of airports. The Federal Targeted Investment Program for 2012 includes 
funding 139 activities with the total volume of state capital investments exceeding 40.68 billion rubles.

Due to the growth of investments of both public and private nature, we can observe the gradual development of airport infrastructure, reconstruction of the existing and construction of new runways, implementation of Electronic Ticketing Systems, development of ground handling services for the growing variety of aircraft (AC) fleet of domestic and foreign manufacture, etc. Growth of capital investments funded by the state budget into the airport development in 2013 amounted to over 46 billion rubles (instead of 1 billion rubles in 2002), but since the early 1990s, the total amount of underfunding for this sector of industry is estimated at more than 1.25 trillion rubles. Implementation of specific types and forms of funding primarily depends on the airport's organizational and legal system (OLS) (Table 1).

Table 1. Types and forms of airport funding based on different types of the organizational and legal system (Volkova, 2011)

\begin{tabular}{|c|c|c|c|c|}
\hline \multirow[b]{2}{*}{ OLS } & \multicolumn{4}{|c|}{ Form of financial resources attraction } \\
\hline & $\begin{array}{l}\text { Internal funds } \\
\text { (profit) }\end{array}$ & 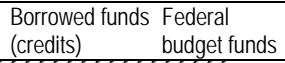 & $\begin{array}{l}\text { Funds of Funds of } \\
\text { investors shareholders }\end{array}$ & $\begin{array}{l}\text { Public-Private } \\
\text { Partnership (PPP) }\end{array}$ \\
\hline $\begin{array}{l}\text { Federal State Unitary Enterprise } \\
\text { (FSUE), owned share } 51 \% \\
\text { Open Joint Stock Company (OJSC) } \\
\text { FSUE, owned share starting from } 5 \% \\
\text { Private ownership }\end{array}$ & 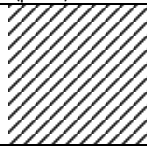 & weyely & $4 /$ & $\%$ \\
\hline
\end{tabular}

As shown in Table 1, a single source of funding for an airport enterprise operation is not enough. Being privately owned, enterprises stimulate interest of investors. For development of airport enterprises, it is necessary to attract different sources of investment resources needed: credit funds, budgetary funds, and internal funds of airport enterprises.

Airport demand in financial resources is caused by a large number of different industrial complexes that feature individual level of importance and varying level of technical validity. Analysis of the current state of airport's industrial complexes, facilities, and installations defines an approximate distribution of capital investments as follows: internal funds and credits are used for funding the entire complex of objects. Terminals and facilities of the service and technical area are funded through all types of sources listed in the abovementioned Table. Hangars and fuel storage terminals are funded both through the airport's internal and credit funds or investments as well as through the funds of its shareholders. Projects of the public-private partnership (PPP) are the most significant for the airfield installations, terminals, and facilities located on the service and technical area.

Thus, a preliminary study of contemporary problems and challenges faced by airport enterprises has shown that in Russia, most of them require modernization of the existing infrastructure and expansion of the production capacity of buildings and facilities located both on the airfields and within the service and technical areas. Implementation of these projects involves considerable investments. And investment decisions require an adequate technique for evaluation of investment attractiveness of airport enterprises (IAAE), which could provide investors with an idea of specific indicators characterizing the work of enterprises related to this sector of industry, and of factors that determine the volume and dynamics of passenger traffic, business activity, and stability of existing airports.

\section{Literature Review}

As mentioned above, relevance of the research topic under consideration is associated with the necessity to develop a new method for evaluating the investment attractiveness of an airport enterprise.

In the modern theory and practice, a concept of enterprise's investment attractiveness is used for evaluation of investment decision validity. Study of existing viewpoints on the interpretation of this concept enables us to assert that currently, there is no uniform approach to the essence of this economic category, as well as there is no common mechanism for defining the investment attractiveness of enterprises with regard to their industry characteristics, including the enterprises engaged into airport business. Analysis of the works by Blank (2005), Kreinin (2006) and others concerning this matter has shown that within any type of assessment approaches the concept of "investment attractiveness" is more often than any other definition used for evaluation of advisability for investing into certain objects, choosing alternatives, and calculating implementation efficiency of the funds invested.

According to Raizman, Grishyna and Shakhnazarov (2007), evaluation of investment attractiveness should be carried out in compliance with the indicators of net profit; industry-specific social and environmental outcomes, as well as indirect financial results. Integral index of investment attractiveness, according to these authors, can be defined by such 
criteria as the level of profitability, level of development prospects, and risk component. According to Pakhomov (2009), the generalizing factor of an enterprise's investment attractiveness is its business reputation, which assessment is based on the progress achieved in economic activity, brand stability in the market, and the image of a reliable partner within the business environment. In our opinion, one of the most precise interpretations of an enterprise's investment attractiveness from an economic point of view was given by Endovitskiy (2010): "a set of objective features, properties, means, and opportunities that provides for potential effective demand for investments." However, this definition covers a very wide range of elements, but does not take into account industry-specific features and factors that can attract investment resources of parties concerned.

There are also other points of view regarding the concept concerned and calculation methods. A sufficiently complete idea of the investment attractiveness is expressed in the definition given by Krylov, et al. (2003). The subject matter of the investment attractiveness is normally taken to mean the economic category, which is characterized by the efficiency of assets use, financial solvency, financial stability of the enterprise, its potency for developing against the background of investment profitability growth, increase in performance indicators, improvement of the product's quality and competitiveness.

Geetha and Ramesh (2012) studied the demographic factors that affected such investment decision elements as sex, age, education, occupation, level of incomes, savings, and family size. Bialowolski and Weziak-Bialowolska (2014) emphasized the importance of external factor influence on the investment decision using Polish companies as an example. Results show that for evaluation of investment decisions, the key external factors are macroeconomic factors and laws.

An analysis of the literature concerning the study matter showed that there was a small number of writers in Russia, who were engaged in this issue in the sphere of airport business. Estimations by Zaitseva (2007) in the matter of defining investment attractiveness from the perspective of income acquisition and certain risk attachment are available, wherein the income generation (economic impact of investment activities) should occur at minimum values of the risk component. In addition, according to this author, whose opinion should be agreed with, nowadays, there are no universal techniques for evaluation of investment attractiveness of enterprises engaged in various branches of industry, including the airport enterprises, even if taking into consideration those techniques that are currently applied in practice.

The IDEAS-space analysis shows that foreign scientists show considerable interest in the problem being investigated. Thus, Conventz and Thierstein (2011) point out in their article that investments made in the airfield infrastructure have finally transformed regional airports with their hinterlands into complexes with high level of transport accessibility. The results of their studies also show that airports and their surroundings have recently become an attractive location for the development of real estate business among the enterprises that work in the highly globalized sectors of industry. The authors emphasize that in general, airports play an important role in the development of the areas surrounding cities. A similar idea is expressed in the article by Bogdanski. (2014), which describes significant growth in transport mobility, improvement of competitiveness and investment attractiveness of the region, and as a consequence, rise of the social and economic level of development after establishment of a regional airport due to the funds invested into modernization of the military airport in Szymany near Szczytno. The article written by Robertson (1995) is devoted to the issues concerning the growth of airports' potential and their impact on the development of neighboring regions. The author proves that airports can significantly affect the level of population employment in the region and provide for the tourism and industry development.

Morgado, Nagaralu, Macario and Neufville (2011) in their study conclude that investment decisions are made when assessing the currently excessive or growing potential demand. In assessing the demand, the authors suggest to use forecasting techniques based on the calculation of NPV, project sensitivity analysis, which in their opinion, will increase the attractiveness of investing in the modernization of runways and terminal capacities.

Falck (2014) considers the factors of foreign direct investments in the region and industry as follows: market potentials, agglomeration economies, transport infrastructure, and factor costs. Based on the regression analysis, his study demonstrates a close link between direct foreign investments in the economy of Sweden and diversification of the regional economy, good access to international airport, and qualified labor force.

In their article, Fernandes and Capobianco et al. (2001) show that the civil aviation industry typically needs major investments from own and borrowed funds sources. The article Littlechild, by Stephen (2012) demonstrates that investments in airports carried out through the internal funds substantially depend on the level of market-specific regulation of transportation rates. While studying the sources of airport infrastructure funding in Argentina, Lipovich (2008) proved that the major investments can be drawn from the private sector.

In their research work, Beria and Scholz (2010) analyzed the investment projects involving funds invested into the European airports-the Milan Malpensa Airport and the Berlin Brandenburg International Airport. Forecasts of air 
transportation demands are taken as a basis for investment decision making. Anming and Yimin (2010) have proved that when assessing investment attractiveness of airports, it is required to consider the indicators of effectiveness and efficiency, which will differ for public and private airports. An analysis of investments in the airports of Spain carried out by Martin-Cejas (2002) showed that the airport size is a significant factor of airport investment planning.

Cui, Kuang, , Wu and Li (2013) studied the problems of Chinese airports competitiveness under the conditions of the Chinese economy's rapid growth. The authors proposed the index of airport competitiveness calculated based on the indices of Regional Development, Production Factors, Demand Conditions, and Industry Support. The authors noted that this index would be significantly influenced by investments in airports.

In their research, Homsombat, Lei and Fu (2011) studied the factors that determine the operation efficiency and availability of investments in the major airports of South-East Asia. Negative factors associated with political instability in the region and affecting the demand level were highlighted. Positive factors of traffic growth included availability of low cost carriers.

The article written by Lubbe, Douglas and Zambellis (2011) demonstrates that investments made in the airport personnel will have a significant impact on the operation efficiency and quality of traveler services. In their article, Hooper and Hensher (1997) studied the tendencies for corporatization and privatization of airports in order to improve their performance and quality of customer services.

Appold and Kasarda (2006) revealed a significant impact of demographic factors on the volumes and nature of retail sales and consumption of non-aviation related services at airports, which can increase the validity of investment decisions in the expansion of trade zones in airports.

Within the framework of our study, we understand the investment attractiveness of airport enterprises as a system of characteristics (of macroeconomic and microeconomic levels of management) allowing potential investors to assess how a certain investee can be more attractive compared to other investment opportunities within the infrastructure facilities of the transport industry.

\section{Methodology}

We studied the performance features of airport enterprises, as well as the efficiency and effectiveness indices of their commercial activity. We found out that the business activity, income indicator of aviation and non-aviation services, and overall attractiveness from the perspective of a potential investor significantly depend on one of the main volumetric indices-the passenger traffic of an airport enterprise. The volume of passenger traffic is influenced by domestic factors, which in turn significantly affect the external regional factors generating the need for air travels of employees working in the companies that are located on the territory of the region where the airport is located, as well as on the average salary in the region, which together stimulate private travelling by air.

In our opinion, we can single out the following key factors that influence on the results of operation performance of airport enterprises that in turn affect the indices of passenger traffic capacity and income acquisition by airports (Figure 1). 


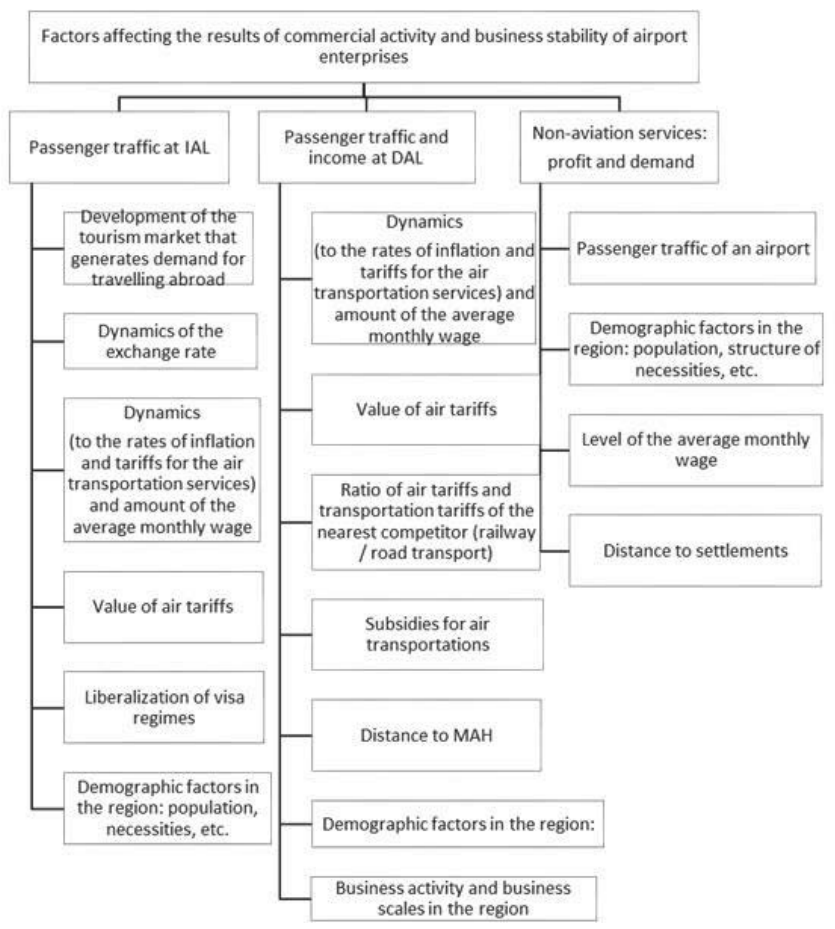

Figure 1. Factors determining the results of commercial activity of airport enterprises

It should be also noted that in the past few years, a tendency of increasing the share of non-aeronautical revenues (60$70 \%$ ) is typical for most airports around the world. But in Russia, this trend is being actively developed only by the MAH airports and some major regional centers (Tolmachevo \& Koltsovo, etc.). Being caused by the contemporary crisis phenomena in national economy, the decrease in the effective demand for air transportation, accompanied by a reduction of volumetric indicators of civil aviation and problems with profitability of airlines, has led to a decline in the level of conventional aeronautical revenues of airports. In the current situation, it is advisable for the top management of airports to reconsider the development strategy and focus on maximization of revenues through increasing the share of nonaeronautical revenues. Such revenues can be obtained from rendering services to a wide range of customers: in case of $B 2 B$ business - to air carriers, enterprises located within the airport territory, etc., and in case of $B 2 C$-to passengers, visitors, and airport personnel, residents of the nearby settlements. Corporate demand $(B 2 B)$ depends on the level and condition of business activity in the region, which affects the dynamics of industrial production in the region and foreign trade. It is mainly manifested in the international airlines (IAL). According to Sinitskiy, Borisov and Kramarenko (2014), personal consumption of air transport services (B2C) is to a greater extent correlated with the wages and money incomes of population, as well as with the changes in exchange rates (it is relevant to the transportation on IAL). As a rule, the non-aeronautical revenues make up only a small (up to $30 \%$ ) share of the total value of revenues obtained by regional airports.

Internal factors generally affecting the attractiveness of the airport business largely reflect the macroeconomic processes at the level of regional, national, and world economy.

An analysis of the performance features of airport facilities in Russia allows us to identify a number of factors and specific characteristics that have a significant impact on the investment decisions making:

1) Passenger traffic of an airport enterprise influencing the internal revenues of an airport, and business activity of non-aviation enterprises located within the airport territory. In our opinion, passenger traffic of an airport enterprise is most essentially influenced by the aviation-related mobility of the population. This factor is crucial when organizing related services (hotels, cafes, restaurants) in the major air hubs. However, influence of this factor will decline in the regional airports featuring low passenger traffic. In smaller towns, passengers arriving 
at the airport shortly before landing are not morally ready to take advantage of paid services provided by the public parking or catering establishments, etc. In this regard, the percentage of passengers performing private trips (tourism, travels, family circumstances), and percentage of passengers sent to business trips (official journeys, conferences, seminars, symposia, etc.) will be important. Wherein, this index will substantially depend on the following factors.

2) The region's economy scale (RES), which involves business activity of enterprises, takes into account the share of profitable enterprises in the economy (SPE), the level of the region's innovative development (IDR), the rating of the region's investment attractiveness (RIA), the characteristic of investment in fixed capital (IFC), the volume of direct foreign investments (DFI), and integral rating of social and economic situation of the region (IRSES).

3) Social, economic, and demographic characteristics of the region (population size (P), life quality rating (LQR), remoteness of the region from Moscow (RM), median wage (MW), etc.).

4) Characteristics of potential passenger traffic, assessment of the airport hinterland (the size and aviationrelated mobility of the population within the distance of up to $150 \mathrm{~km}$ (PP150), up to $300 \mathrm{~km}$, and up to 500 $\mathrm{km})$.

5) The financial and economic stability of an airport enterprise, which determines its future revenues, profitability of economic activity, as well as business activity and ability to be liable for its debts.

Next, we conducted a study of the abovementioned factors for the airports included into the top 10 of Russian airports in terms of passenger traffic index, and six regional airports located in the Far East region.

To create an adequate technique for investment attractiveness evaluation, it is necessary to identify the factors that will have the maximum impact on the interests of potential investors. At the same time, the target audience that is the subject of investment decision-making can be divided into 2 groups: creditors who are interested in earning fast income (percent), and business participants (stakeholders) who are interested in receiving revenues from the rising cost of an economic entity.

The abovementioned factors affect the passenger traffic by stimulating private consumers and enterprises of the region for travel initiating. We have estimated the influence of all the above listed parameters through the indices of a paired and multifactor regression analysis. At the first stage, as a result of pairwise comparison of factorial indicators and the effective indicator-the passenger traffic-we selected factors required for conducting the second stage-the multiple regression analysis featuring high and very high degree of influence. The level of communication is established according to the Chaddock scale.

We identified the functions of the relation of the investment attractiveness of an airport enterprise with the regional factors that have a high level of communication with the indicator of current or potential passenger traffic. They are provided in Table 2.

Table 2. Functions of external (regional) factors influence with the assessment of the investment attractiveness of airport enterprises

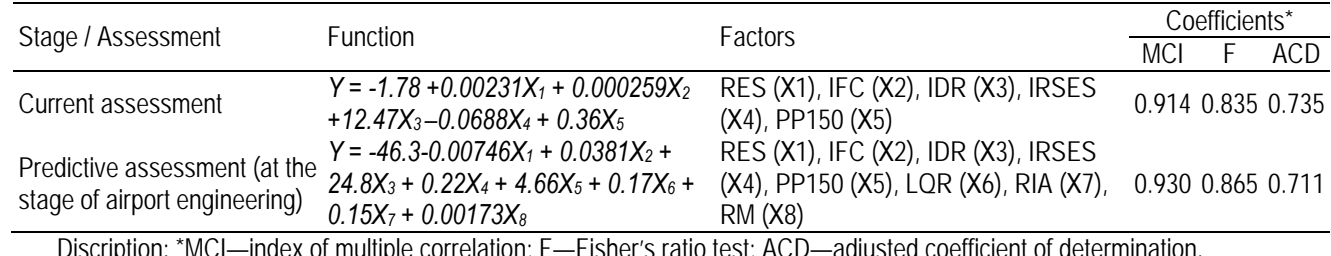

Herewith, this analysis was carried out in two projections: for investors that invest in ongoing activities of airports, and for decision-making that concerns investments made during the stage of engineering.

The coefficients demonstrate a high degree of communication between the indicators studied, which indicates the viability of the model and possibility of its application.

For creating a technique for investment attractiveness evaluation, the assumed regions' ratings are found by such universally recognized Russian economy analysts and experts in the domestic market as NRA (National Rating Agency), the Agency for Strategic Initiatives, the Association of Innovative Regions of Russia, the RIA Rating Agency, and the "Expert RA" Rating Agency. 
In the course of studies, we developed a technique for evaluation of airport enterprise investment attractiveness, which is shown in Figure 2.

The technique for evaluation of airport enterprise investment attractiveness includes the following key elements:

1) Identification of the investment objectives and investee that assumes a preliminary stage of works on the establishment of the investor's position, its initial interests, and conditions for investment of funds. Initially, we assume the condition as follows: investments are only considered in the scope of aviation enterprise activity.

2) The next stage specifies the purposes for investment attractiveness evaluation. An array of data is formed regarding airport enterprises, regions, and other branch indicators, which generate an informational field for an investee. At this stage we clarify the situation of assessment- either investment is planned for an existing airport enterprise (the "current activity" format), or investment is planned during the stage of a new airport engineering. This factor influences both the purpose of evaluation, and indicators, which are further implemented in the analysis of the investee investment attractiveness.

3) After having identified the situation and purpose of investment attractiveness evaluation, the array of data that characterize the factors actively participating in the formation of this evaluation is generated. At this stage, the investment attractiveness of an airport enterprise (IAAE) can be represented as a function of indicators characterizing the development and scales of business in the region (SBR), the socioeconomic indicators(SEI), and the indicators for assessing the economic and financial stability and efficiency (FS) of the airport enterprise activity (Figure 3).

Figure 3 shows the following factors: the number of enterprises in the region $(N)$, turnover of the enterprises $(T)$, the rating of the region's economy scale (RES), the gross regional product (GRP), the level of innovative development of the region (IDR), investments in the main capital (IMC), the rating of investment prospects of the region (RIP), the region's population $(P)$, including urban and rural population $(\mathrm{Pu} \& \mathrm{Pr})$, the population density, including urban and rural population (D, Du, \& Dr), aircraft mobility (AM), average wage in the region (AW), median wage in the region (MW), integral rating of the socioeconomic situation of the region (IRSES), and coefficients $\mathrm{C} 1-\mathrm{C} 8$, which are the relative indicators of the financial stability, such as the coefficient of autonomy, the equity ratio, the current assets to equity ration, etc.

This block of factors is a key determinant when assessing investment projects of airports at the stage of their engineering. Proper assessment of the future effectiveness of an investment project will allow choosing the optimal region, area, and location of the airport with respect to settlements and existing enterprises that form the industrial cluster in the region, etc.

Moreover, we suggest that airports use the Analytic Hierarchy Process in the evaluation of the most preferable methods of correction and programs of airport enterprise indicators when conducting their internal preliminary assessment of investment opportunities. Implementation of this method in relation to the activities of road transportation companies is set out in the work by Borodulina (2012). 


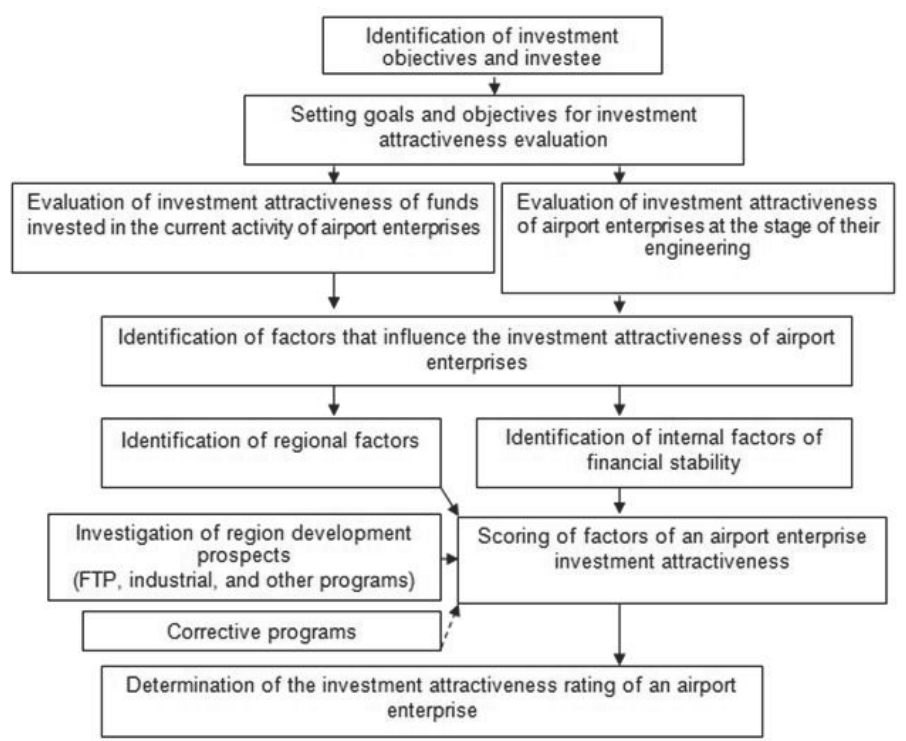

Figure 2. Technique for evaluation of investment attractiveness of an airport enterprise

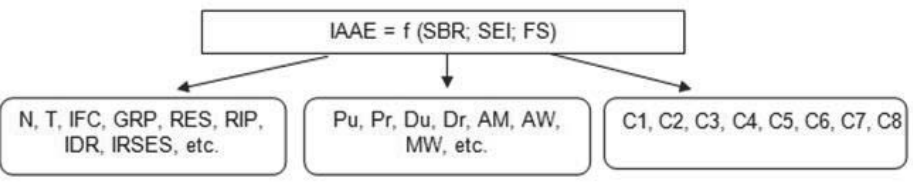

Figure 3. Types of factors influencing the evaluation of IAAE

\section{Results and Discussion}

We processed a large amount of statistical data from 2008 to 2014, public financial statements, and data on the regional ratings from major expert rating agencies. Besides, using the logical method, expert evaluation methods, and materials processing by means of mathematical statistics methods, we identified the elements' class boundaries (the factors of regional investment attractiveness), which are included in the calculation of the investment attractiveness rating of airport enterprises (Table 3). According to the Sturges Rule, we determined the optimal distribution of indicators by five intervals.

The value of the airport enterprise's investment rating can be determined by the following formula:

$I A A E=\sum\left(\mathrm{S}_{\mathrm{ij}} \cdot \mathrm{V}_{\mathrm{ij}}\right) \cdot \mathrm{V}_{\mathrm{RFV}}+\sum \mathrm{S}_{\mathrm{ij}} \cdot \mathrm{V}_{\mathrm{FES}}$

where $S_{i j}$ is a scoring for the $j$-th airport enterprise by the $i$-th indicator. Calculations conducted in accordance with the variant of investment attractiveness evaluation for an existing airport enterprise shall be based on the following data: $i=5$ (RES, IFC, IRSES, IDR, and PP150 are considered as the indicators). Calculations conducted in accordance with the variant of predictive assessment of $A E$ at the stage of airport engineering shall be based on the following data: $i=7$ (RES, IFC, IRSES, IDR, PP150, LQR, RIA, and RM are considered as the indicators);

Vij is the validity of the factors-indicators (RES, IFC, IRSES, IDR, PP150, LQR, RIA, and RM) by each j-th airport enterprise, which is determined by means of an expert method as shown in Table 2;

$V_{R F V}, V_{F E S}$ are the validity of regional factors and indicators of financial and economic stability, which is determined by means of an expert method as shown in Table 2 with regard to all airport enterprises. 
Table 3. Ranking of regional factors by ratings

\begin{tabular}{cccccc}
\hline Factors & Class 1 & Class 2 & Class 3 & Class 4 & Class 5 \\
\hline RES & over 7.357 & $5.524-7.357$ & $3.691-5.523$ & $1.857-3.690$ & below 1.857 \\
IFC & over 1.203 & $906-1.203$ & $607-905$ & $309-606$ & below 309 \\
IDR & over 0.54 & $0.44-0.54$ & $0.33-0.43$ & $0.22-0.32$ & below 0.22 \\
IRSES & over 69.1 & $55.5-69.1$ & $41.8-55.4$ & $29-41.7$ & below 29 \\
PP150 & over 9.6 & $9.6-7.3$ & $7.2-4.9$ & $4.8-2.5$ & below 2.5 \\
LQR & over 66 & $51-66$ & $34-50$ & $18-33$ & below 17 \\
RIA & over 66 & $51-66$ & $34-50$ & $18-33$ & below 17 \\
RM & below 1.394 & $1.395-2.788$ & $2.789-4.182$ & $4.182-5.576$ & above 5.576 \\
\hline
\end{tabular}

Methods of mathematical statistics were used to determine the optimal number of ranks equal to six. Characteristics of each rank based on the data on airport enterprises, logical analysis, and expert surveys are given in Table 4.

This technique was tested by means of simulating calculations in the format of "current AE activity." The following ranks were obtained for the airport enterprises of the Far East region: OJSC "Khabarovsk Airport"-rating 1.75 (rank 5), the Kamchatka Region SUE "Kamchatka Aviation Enterprise"-rating 1.92 (rank 5) respectively, FSUE "Magadan Airport"-rating 2.22 (rank 5), OJSC "Vladivostok International Airport"-rating 1.30 (rank 6), FSUE "Yuzhno-Sakhalinsk Airport"-rating 2.43 (rank 4), OJSC "Yakutsk Airport"-rating 1.46 (rank 6).

Table 4. Boundaries of the IAAE rating

\begin{tabular}{ccl}
\hline Rank & $\begin{array}{c}\text { Rating } \\
\text { boundaries }\end{array}$ & Characteristic of the AE group \\
\hline 1 & $4.35-5.0$ & AE with high values of FES and RFV, and therefore possessing considerably high IAAE rating \\
2 & $3.68-4.34$ & AE with considerably high values of FES and RFV, and therefore possessing high IAAE rating \\
3 & $3.01-3.67$ & AE with average or high values of FES and low values of RFV, and therefore possessing average IAAE rating \\
4 & $2.34-3.00$ & AE with average and low values of FES, and average values of RFV, and therefore possessing IAAE rating \\
5 & $1.67-2.99$ & AE with average and low values of FES, and low values of RFV, and therefore possessing low IAAE rating \\
6 & $1.0-1.66$ & AE with low values of FES and low values of RFV, and therefore possessing extremely low IAAE rating \\
\hline
\end{tabular}

Rating boundaries and optimal distribution by intervals are determined according to the Sturges Rule (with no restrictions on the number of intervals) subject to the values by 44 regional airport enterprises, according to which the available public reports were obtained. Intervals and sample mode were graphically determined. Thus, the most common value of the IAAE rating according to the study group of airports was 2.12. The median value of indicator by the group was 2.86 .

\section{Conclusion}

Using the calculations on the technique developed by us, a potential investor will be able to determine the rank of the airport enterprise's investment attractiveness, and thus make informed investment decisions.

According to the results of our study, we can conclude that:

1) A relevant technique for evaluation of the airport investment attractiveness was developed, allowing investors to assess and account for the factors influencing on the future workload and degree of airport infrastructure usage. Besides, this technique will allow investors to determine the investment rating of a potential investee in comparison with similar enterprises in this industry sector.

2) It was proved that differences in assessment of the results obtained and the project effect arise during the process of investment in the airport business. It was also shown that evaluation of the airport investment attractiveness from the perspective of each party concerned is needed.

3) It was proved that investment attractiveness, as a comprehensive assessment of an airport enterprise, is expressed by the rating index of investment attractiveness, which includes a set of selected parameters comprising regional factors identified in the multifactor regression analysis, as well as by the current state indicators of the airport financial stability.

4) Regional development factors should be taken into account when calculating the rating investment index of an airport enterprise under condition of two forms of assessment: the current assessment and the assessment at 
the stage of airport engineering.

5) Scoring of selected factors was performed with regard to their validity determined by expertise. The investment rating was determined through the method for identification of classes and ranks of the airports investment attractiveness. A characteristic allowing investors to make informed investment decisions was developed for each rank of investment attractiveness.

This study should be further extended by evaluation of the investment expediency from the perspective of investor - an airline based in the airport complex. In order to perform this type of evaluation, such elements of airport investment attractiveness growth as potential pricing mechanisms should be considered. These are, for example, reducing air transportation tariffs, offering bonuses to travelers, additional safety guarantees, and provision of new nonaviation services. These factors, if combined with the previous ones, can significantly influence on the investment rating of an airport enterprise.

\section{References}

Anming, Z., \& Yimin, Z. (2010). Airport capacity and congestion pricing with both aeronautical and commercial operations. Retrieved from https://ideas.repec.org/a/eee/transb/v44y2010i3p404-413.html

Appold, S. J., \& Kasarda, J. D. (2006). The appropriate scale of US airport retail activities. Retrieved from http://www.sciencedirect.com Iscience/article/pii/S0969699706000378

Beria, P., \& Scholz, A .B. (2010). Strategies and pitfalls in the infrastructure development of airports: A comparison of Milan Malpensa and Berlin Brandenburg Int. Retrieved from https://ideas.repec.org/a/eee/jaitra/v16y2010i2p65-73.html

Bialowolski, P., \& Weziak-Bialowolska, D. (2014). External factors affecting investment decisions of companies. Retrieved from http://www.economics-ejournal.org/economics/journalarticles/2014-11

Blank, I. A. (2005). Investment Management. Kiev: Elga-N.; Nika-Centre.

Bogdański, M. (2014). Airports as a factor of regional development on the example of the Szymany Airport. Retrieved from http://www.bulletinofgeography.umk.pl/25_2014/Bogdanski.pdf

Borodulina, S. A. (2012). Methodology for Process Management of A Road Transport Enterprise under Conditions of a Non-Stationary Development. Sankt-Petersburg: Publishing house of the St. Petersburg State Engineering and Economic University.

Fernandes, E., \& Capobianco, H. M. P. (2001). Airline capital structure and returns. Retrieved from https://ideas.repec.org/a/eee/jaitra/ v7y2001i3p137-142.html

Morgado, F., Nagaralu, S. S., Macario, R., \& de Neufville, R. (2011). Value of Options in Airport Expansion-Example of AICM. Retrieved from http://www-sre.wu.ac.at/ersa/ersaconfs/ersa11/ e110830aFinal00149.pdf

Geetha, N., \& Ramesh, M. (2012). A study on relevance of demographic factors in investment decisions. Retrieved from http://academic publishingplatforms.com/downloads/pdfs/pieb/volume10/201206240706_02_PIEB_Vol10_Issue1_2012_Geetha_and_Ramesh_ Demographic_factors_investment_decisions_pp.14-27.pdf

Qiang, C., Hai-bo, K., Chun-you, W., \& Ye, L. (2013). Dynamic formation mechanism of airport competitiveness: The case of China. Retrieved from https://ideas.repec.org/a/eee/transa/v47y2013icp10-18.html

Endovitskiy, D. A. (2010). Analysis of Enterprise Investment Attractiveness. Moscow: Publishing house "KnoRus."

Hooper, P. G., \& Hensher, D. A. (1997). Measuring total factor productivity of airports- an index number approach. Retrieved from http://www.sciencedirect.com/science/article/pii/S1366554597000331

Homsombat, W., Lei, Z., \& Fu, X. (2011). Development status and prospects for aviation hubs- a comparative study of the major airports in South-East Asia. Retrieved from https://ideas.repec.org/a/wsi/serxxx/v56y2011i04p573-591.html

Kreinina, M. N. (2006). Financial Management. Moscow: Publishing house "Delo i Servis."

Krylov, E. I., Vlasova, V. M., Egorova, M. G., \& Zhuravkova, I. V. (2003). Analysis of Financial Status and Investment Attractiveness of Enterprise. Moscow: Publishing house "Finance and statistics."

Lipovich, G. A. (2008). The privatization of Argentine airports. Retrieved from https://ideas.repec.org/a/eee/jaitra/v14y2008i1p8-15.html

Lubbe, B., Douglas, A., \& Zambellis, J. (2011). An application of the airport service quality model in South Africa. Retrieved from http://www.sciencedirect.com/science/article/pii/S0969699710000815

Littlechild, S. C. (2012). Australian airport regulation: Exploring the frontier. Retrieved from https://ideas.repec.org/a/eee/jaitra/v21y 2012icp50-62.html

Martin, J. C., \& Pilar, S. M. (2009). A new era for airport regulators through capacity investments. Retrieved from https://ideas.repec.org la/eee/transa/v43y2009i6p618-625.html

Okuneva, A. A. (2013). Technique for Estimation of Financial Stability of an Airport Enterprise Based on Integral Indicators. Economy and Management Journal: Russian Scientific Journal, 11(97).

Pakhomov, V. A. (2009). Factors of Enterprise Investment Attractiveness. Moscow.

Raizman, I. I., Shakhnazarov, A. G, \& Grishyna, I. V. (2007). Evaluation of Investment Project Effectiveness: Account of Regional Risks. Investments in Russia Journal, 10.

Martin-Cejas, R. R. (2002), An approximation to the productive efficiency of the Spanish airports network through a deterministic cost frontier. Retrieved from http://www.sciencedirect.com/science/article/pii/ S0969699701000564

Robertson, J. A. W. (1995). Airports and economic regeneration. Retrieved from https://ideas.repec.org/a/eee/jaitra/v2y1995i2p81- 
88.html

Simon, F. (2014). Location of Foreign Direct Investment in Services: Some Cross-industrial Evidence from Sweden. Retrieved from https://ideas.repec.org/a/cai/rerarc/reru_142_0285.html

Sinitskiy, A., Borisov, F., \& Kramarenko, A. (2014). Limits of Air Transportation Growth in Russia. Retrieved from http://www.ato.ru/ content/predely-rosta-aviaperevozok-v-rossii

Conventz, S., \& Thierstein, A. (2011). The knowledge economy, hub airports and accessibility. A location based perspective. Retrieved from https://ideas.repec.org/p/wiw/wiwrsa/ersa11p1569.html

Volkova, L. P. (2011). Airport Operation Management. Moscow: Publishing house of the Moscow State Technical University of Civil Aviation.

Zaitseva, N. (2007). How to Evaluate Investment Attractiveness. BBW Journal: Banks and Business World, 12. 